\title{
The impact of the Tri-City Ring Road on surface water of small endorheic wetlands
}

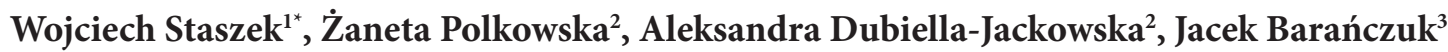 \\ ${ }^{1}$ Department of Physical Geography and the Environmental Management, University of Gdańsk, Bażyńskiego 4, 80-309 Gdańsk, Poland, \\ e-mail: geosw@ug.edu.pl (*corresponding author) \\ ${ }^{2}$ Department of Analytical Chemistry, Gdańsk University of Technology Narutowicza 11/12G, 80-952 Gdańsk, Poland, \\ e-mail: zanpolko@pg.gda.pl; aledubie@pg.edu.pl \\ ${ }^{3}$ Department of Limnology, University of Gdańsk, Bażyńskiego 4, 80-309 Gdańsk, Poland, e-mail: bgiojb@univ.gda.pl
}

\begin{abstract}
The paper presents the results of the impact of the Tri-City Ring Road on small endorheic catchment basins. Particular attention was paid to pollution discharged from the road to the surface water, as well as changes in hydrological conditions in the vicinity of the road. In the study, surface water samples were analysed in terms of their electrolytic conductivity, $\mathrm{pH}$ and content of major minerals. GIS was also used to study transformation of local catchment areas as a result of the road construction, determining their relevance to local conditions of drainage. Moreover, the main directions of transformation of surface waters of the small endorheic wetlands caused by runoff water from the ring road were discovered. Research results have shown a strong influence of the road functioning on surface water properties and changes in hydrological conditions of the studied catchment basins.
\end{abstract}

Key words: road runoff, endorheic basins, wetlands, water chemistry

\section{Introduction}

In recent years, more and more attention has been paid to the interaction of surface and linear sources of pollution to changes in water chemistry. This group includes transport routes that could significantly affect the aquatic environment. This was confirmed by studies on rain and snowmelt runoff carried out in the 1990s and later in Poland (Osmulska-Mróz and Sadkowski 1991; Osmulska-Mróz 1997; Polkowska et al. 2001), as well as outside the country (Marsalek et al. 2003; Thunqvist 2003; Westerlund et al. 2003). The environmental impact of road runoff on the aquatic environment is closely related to the nature of the reservoir to which they are discharged. Small endorheic basins which are prevalent in the area of the young-glacial landscape are particularly vulnerable and sensitive to the accumulation of pollutants. In the environmental conditions of the research area, the eastern part of the Plateau of Gdansk, a substantial proportion of them are genetically related to the acidic oligo-dystrophic wetlands of predominantly ombrogenic water management. Due to the nature of the water management, trophism level, characteristics of the catchment basin and their frequently small size, the above mentioned group of wetlands and ponds (small water bodies) is particularly sensitive to changes in the supply of water and pollutants.

This study deals with the causes and trends of the changes in water ecosystems due to the operation of expressways. In such cases, the crucial factor for change is the impact of polluted runoff from roads on the aquatic environment.

As a significant expansion of road network, including motorways, is being planned in Poland, it seems particularly important to undertake research on their impact on the functioning of the hydrochemical circle of endorheic basins and their ecosystems.

\section{Study area}

A forested section of the Plateau of Gdansk was selected as a research area. This area is located within the undulated postglacial morainic plateau, characterized by the presence of numerous ponds and wetlands concentrated especially within small outflowless catchments. A section of the Tri-City Ring Road passes through this area. Traffic congestion there is very high and amounts to over 50 thousand vehicles per day. The area is also part of the Tri-City Landscape Park. The research program concentrated on the ring road section 


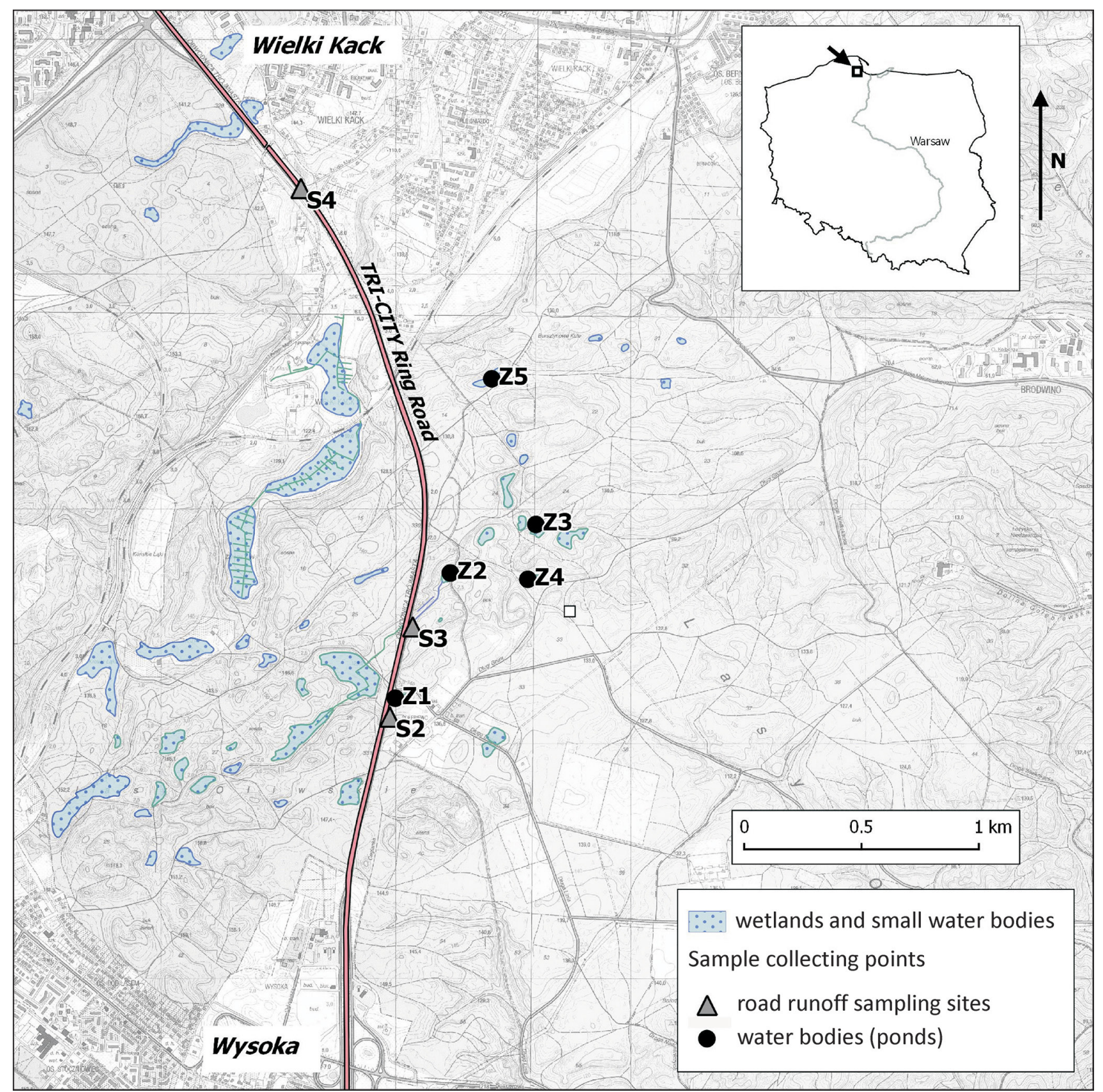

Fig. 1. Location of the researched outflowless basins with wetlands and sample collecting points

of approximately $3.0 \mathrm{~km}$ between Wysoka junction and Wielki Kack junction (Fig. 1).

The small water bodies and wetlands in the study area are characterized by a typical ombrogenic water cycle. Therefore, in natural conditions the chemical composition of their waters is solely affected by rainwater. The majority of the aquatic and bog ecosystems, exist in connection with the wetlands. With a diverse, typical young-glacial relief, some of the road runoff is directed to the local wetland basins (compare $\mathrm{Z} 1$ and Z2 - Fig. 1).

\section{Methods}

The studies focused on recognizing the changes in the physical and chemical properties of water of wetland habitats under the influence of runoff from the Tri-City Ring Road. In order to carry out this research studies were undertaken on the physical and chemical properties of the water of selected natural unaffected wetlands. Simultaneously, wetland basins of similar origin and hydrological conditions which receive runoff from the Tri-City Ring Road were studied. Water sam- 
ples for testing physical and chemical properties were collected in specially selected, most representative sites. The measuring network consisted of three checkpoints to control runoff from roads, and five sampling points for the surface water of the wetlands (Fig. 1). The study of the surface water was related to small endorheic wetland basins, two of which are influenced by the runoff from the surface of the ring road (points $\mathrm{Z} 1$ and $\mathrm{Z} 2$ Fig. 1). The other three of natural character are located at a distance from the ring road and have no hydrological contact with it (Z3, Z4, Z5 - Fig. 1). Such a measurement network consisted of permanent sampling points, as presented in Table 1 .

The samples, collected at individual points, were taken to the laboratory and analysed. The analyses were conducted during the period from January 2006 until April 2009. Samples from the endorheic areas were collected every month, except for certain months of winter and summer, due to deep freeze, or loss of the visible water table during droughts.

In total, 234 samples (113 from ponds and wetlands and 121 representing the road runoff) were collected and analyzed. Tests were made in the laboratory of the Department of Analytical Chemistry of the Technical University of Gdansk, and included measurements of the concentrations of the basic anions $\left(\mathrm{Cl}^{-}, \mathrm{SO}_{4}{ }^{2-}, \mathrm{NO}_{3}{ }^{-}\right.$ ), and cations $\left(\mathrm{Ca}^{2+}, \mathrm{Mg}^{2+}, \mathrm{Na}^{+}, \mathrm{K}^{+}\right)$.

All determinations were made on the ion chromatograph Dionex-500. Measurements of $\mathrm{pH}$ and conductivity were taken directly in the field using a multiparameter $\mathrm{pH} /$ Cond 340i of the WTW company. The statistical analysis of the results was performed using the software Statsitica 8.0.

A valuable complement to the measurement network was a YSI 6820 Multi-Parameter Water Quality Sonde, which allowed the simultaneous recording of changes in water level, temperature and electrical conductivity as well as dissolved oxygen over a given time span (15 or $30 \mathrm{~min}$ ). The recording devices operated at selected periods of the year, specific and sensitive in terms of the

Table 1. Characteristics of rainwater, runoff and surface water sampling sites

\begin{tabular}{|c|c|c|}
\hline $\begin{array}{l}\text { Sampling } \\
\text { site }\end{array}$ & $\begin{array}{l}\text { Geographical } \\
\text { coordinates }\end{array}$ & Sample type \\
\hline S2 & $18^{\circ} 29^{\prime} 29^{\prime \prime}$ E $54^{\circ} 26^{\prime} 48^{\prime \prime} \mathrm{N}$ & \multirow{3}{*}{$\begin{array}{l}\text { Runoff from the Tri-City Ring } \\
\text { - Road }\end{array}$} \\
\hline S3 & $18^{\circ} 29^{\prime} 31^{\prime \prime}$ E $54^{\circ} 26^{\prime} 48^{\prime \prime} \mathrm{N}$ & \\
\hline S4 & 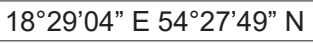 & \\
\hline Z1 & $18^{\circ} 29^{\prime} 27^{\prime \prime}$ E $54^{\circ} 26^{\prime} 37^{\prime \prime} \mathrm{N}$ & \multirow{2}{*}{$\begin{array}{l}\text { Water bodies (small } \\
\text { ponds) and wetland areas } \\
\text { additionally charged by the } \\
\text { runoff from the Ring Road }\end{array}$} \\
\hline $\mathrm{Z2}$ & $18^{\circ} 29^{\prime} 40^{\prime \prime}$ E $54^{\circ} 26^{\prime} 54^{\prime \prime} \mathrm{N}$ & \\
\hline Z3 & $18^{\circ} 30^{\prime} 00^{\prime \prime}$ E $54^{\circ} 27^{\prime} 01^{\prime \prime} \mathrm{N}$ & \multirow{3}{*}{$\begin{array}{l}\text { Natural water bodies (small } \\
\text { - ponds) and wetland areas }\end{array}$} \\
\hline Z4 & $18^{\circ} 29^{\prime} 59^{\prime \prime}$ E $54^{\circ} 26^{\prime} 54^{\prime \prime} \mathrm{N}$ & \\
\hline Z5 & $18^{\circ} 29^{\prime} 50^{\prime \prime}$ E $54^{\circ} 27^{\prime} 21^{\prime \prime} \mathrm{N}$ & \\
\hline
\end{tabular}

impact of the road on surface water in the environment (the period of spring thaw). They provided important information regarding the variability of the properties of runoff water in this period, which were impossible to obtain using random sampling for laboratory tests.

Additionally, to determine the changes in the primary ranges of the catchment basins and the conditions of the surface drainage the GIS software Mapinfo Professional 10.0 was used, together with updated and archival topographic maps and detailed road construction maps.

\section{Results}

The most important factor affecting the hydrochemical regime of the examined wetlands and ponds is the runoff from the road surface. It supplied two (Z1 and Z2) of the five test endorheic basins and was characterized by very high values of the analyzed hydrochemical indicators. On average, in the period from January to April, melt runoff of a different course and intensity mainly came from the loss of long lasting snow cover. It showed very high electrolytic conductivity (SEC), ranging mostly between 1000 and $10,000 \mu \mathrm{S} \mathrm{cm}^{-1}$, with a maximum of over $33,000 \mu \mathrm{S} \mathrm{cm}^{-1}$. In the remaining period of the year rain runoff occurred. Its conductivity was maintained at $150-1000 \mu \mathrm{S} \mathrm{cm}{ }^{-1}$, increasing again after the first snowfall depending on when it occurred during the study period (November-January).

The studied runoff cases showed a very high concentration of major ions, especially chloride and sodium as well as calcium and sulphates. The $\mathrm{pH}$ values were also significantly higher, i.e. slightly alkaline. Both in the snowmelt and rainfall runoff they were around $\mathrm{pH}$ 7.5. The properties of runoff water during the study period and their seasonal variations were clearly related to the snowy winter time when road maintenance substances are used. High values of conductivity and concentrations of individual ions are confirmed by the results of previous studies conducted in Poland (Osmulska-Mróz and Sadkowski 1991; Osmulska-Mróz 1997).

The quoted data on the variation of conductivity, $\mathrm{pH}$ and content of individual ions in runoff water refer only to determinations of samples collected for laboratory testing. Much greater variation of conductivity and $\mathrm{pH}$ could be recorded due to the installation of devices for remote measurements of conductivity, $\mathrm{pH}$ and water oxygenation (meter YSI 6820).

The meter was installed in the area of water runoff marked as a research point S2. The recorded parameters correspond to the disturbance of water chemical properties of the natural waters of ombrogenic peat bog forest under the influence of runoff from the expressway. One of the recorded measurement series referred 

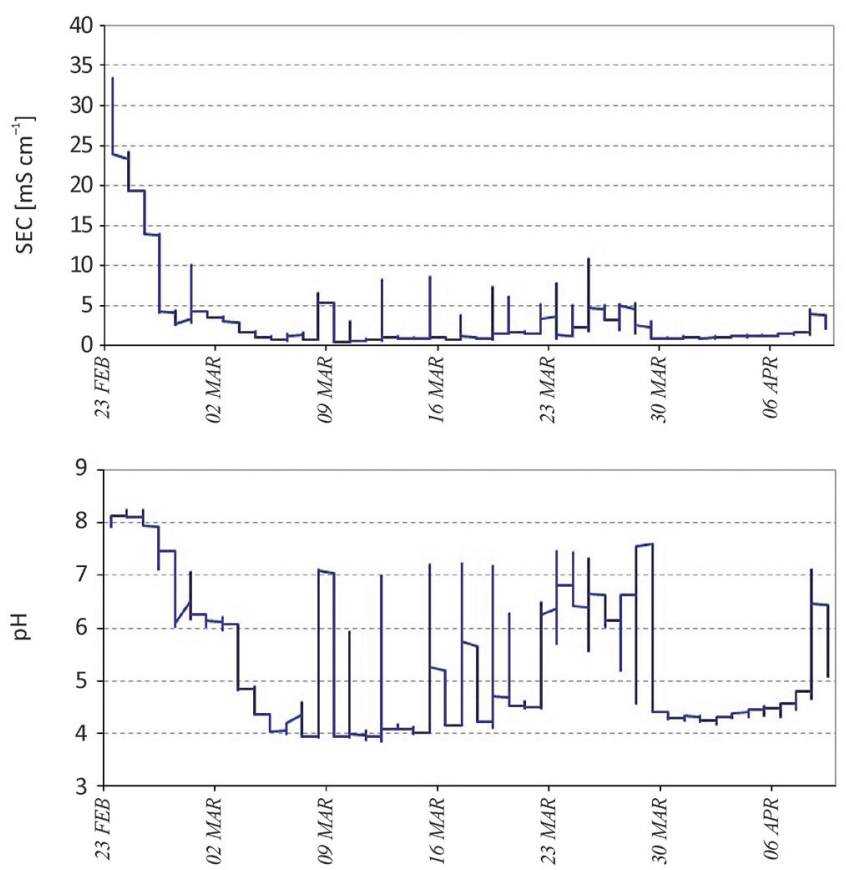

Fig. 2. Variation of specific conductivity (graph above) and $\mathrm{pH}$ (graph below) of runoff from the road between 23 February and 9 April 2009 registered by the YSI 6820 Multi-Probe with a measurement time resolution of 15 minutes

to the neuralgic thawing period in the late winter and spring of 2009. The maximum values of the electrical conductivity of water runoff discharged into waters of the wetlands that occurred during testing in February 2009 , reached (but at the slightly low runoff volumes) over $33000 \mu \mathrm{S} \mathrm{cm}^{-1}$ (i.e. a value three times higher than the recorded average in the marine waters of the Gulf of Gdansk). The period of very high concentration of dissolved minerals and the related water conductivity at the runoff $>10,000 \mu \mathrm{S} \mathrm{cm} \mathrm{cm}^{-1}$, was maintained for the first three days of snowmelt runoff, i.e. from 23 to 26 February 2009 (Fig. 2).

The following period, from February to the end of March, is crucial for understanding the formation of the properties under the influence of surface water runoff from the ring road. It contained long periods of stabilization of water conductivity at about 1000-2000

Table 2. Basic statistics summarize a set of observations of specific conductivity (SEC, in $\mu \mathrm{S} \mathrm{cm}^{-1}$ ) and $\mathrm{pH}$ of the surface runoff from the Ring Road (February-April 2009)

\begin{tabular}{lcc}
\hline \multicolumn{1}{c}{ Descriptive statistics } & SEC & $\mathrm{pH}$ \\
\hline Mean & 3102.29 & 5.28 \\
\hline Median & 1462.00 & 4.62 \\
\hline Standard deviation & 4910.44 & 1.27 \\
\hline Standard error & 74.44 & 0.02 \\
\hline Minimum & 449.00 & 3.85 \\
\hline Maximum & 33432.0 & 8.24 \\
\hline Number of samples & 4351 & 4351 \\
\hline
\end{tabular}

$\mu S \mathrm{~cm}^{-1}$ with waves of very explicit strong increase due to the fact that thawing or rainfall runoff activated the substances lying on the road and its roadsides (Fig. 2).

Temporarily, increases in water conductivity correlate with increases in water $\mathrm{pH}$, clearly indicating the anthropogenic alkalinisation of the water environment in the study area associated with the impact of the ring road. Statistical characteristics of data obtained from remote measurements of water parameters (Table 2) are specific. They take into account 4351 measurements made at 15-minute intervals.

It is significant that the obtained mean values and medians correspond with the acidic reaction of $\mathrm{pH}$ 4.6-5.3. This indicates that this period was dominated by acidic water, typical of natural water from the outflowless wetlands occupied by raised and transitional bogs. Strong increases in $\mathrm{pH}$ caused by the runoff from the ring road were relatively short, but clearly different from the properties of natural waters. These results indicate the main reasons for the diverse characteristics of surface waters in time, indicating the anthropogenic factor to the differentiation of particular hydrochemical classes of water identified in the test area through the use the cluster analysis (Dubiella-Jackowska et al. 2010).

Natural surface waters of small outflowless wetlands and ponds, not impacted by the runoff from the road, showed very low mineralisation. The values of electrical conductivity (SEC) ranged from 30 to $70 \mu \mathrm{S} \mathrm{cm} \mathrm{cm}^{-1}$. They also show an acidic reaction at a $\mathrm{pH}$ of about $5.2-5.4$. There was a very low concentration of basic ions like calcium and magnesium. It rarely exceeded 5 $\mathrm{mg} \mathrm{dm}{ }^{-3}$, ranging mostly from 1 to $3 \mathrm{mg} \mathrm{dm}^{-3}$ (Table 3, Fig. 3-4). These properties are very similar to rainwater (Mazurek and Zwoliński 2001; Kostrzewski and Kruszyk 2010; Tylkowski 2013), which confirms the atmospheric nature of the water supply. Greater similarity to the chemical properties of precipitation in terms

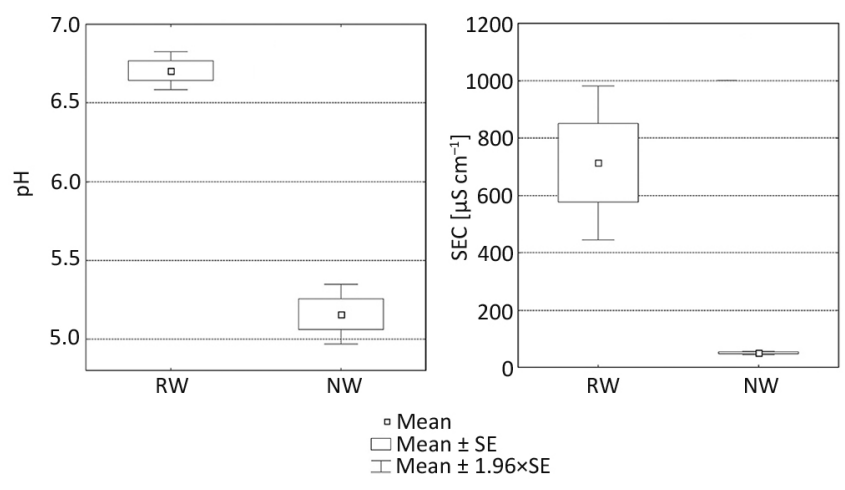

Fig. 3. Mean values of $\mathrm{pH}$ and specific conductivity (SEC) in surface waters

Explanation: RW - wetlands under the influence of runoff from the ring road, NW - natural wetlands 
Table 3. Basic statistics of hydrochemical properties of surface water (NW - natural wetlands; RW - wetlands charged by surface runoff from the Ring Road)

\begin{tabular}{|c|c|c|c|c|c|c|c|c|c|c|}
\hline & \multirow{2}{*}{ Water body/statistics } & \multirow{2}{*}{$\mathrm{pH}$} & SEC & $\mathrm{NO}_{3}^{-}$ & $\mathrm{Cl}^{-}$ & $\mathrm{SO}_{4}^{2-}$ & $\mathrm{Na}^{+}$ & $\mathrm{K}^{+}$ & $\mathrm{Ca}^{2+}$ & $\mathrm{Mg}^{2+}$ \\
\hline & & & {$\left[\mathrm{mS} \mathrm{cm}^{-1}\right]$} & \multicolumn{7}{|c|}{$\begin{array}{ll}\left.\mathrm{mg} \mathrm{dm}^{-3}\right] \\
\end{array}$} \\
\hline \multirow{5}{*}{$\gtreqless$} & Mean & 5.2 & 50 & 1.2 & 4.2 & 8.0 & 7.5 & 4.7 & 3.6 & 0.5 \\
\hline & Median & 5.4 & 46 & 0.4 & 3.7 & 2.7 & 3.0 & 4.4 & 2.9 & 0.3 \\
\hline & Standard deviation & 0.5 & 16.7 & 1.8 & 2.1 & 6.7 & 9.9 & 2.0 & 2.9 & 0.6 \\
\hline & Minimum & 4.2 & 23 & 0.1 & 1.3 & 0.4 & 1.1 & 1.7 & 0.5 & 0.1 \\
\hline & Maximum & 6.0 & 86 & 7.4 & 10.9 & 27.5 & 33.4 & 8.9 & 13.6 & 2.2 \\
\hline \multirow{5}{*}{ 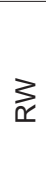 } & Mean & 6.7 & 714 & 3.7 & 159.6 & 17.8 & 78.4 & 5.3 & 15.8 & 2.1 \\
\hline & Median & 6.7 & 484 & 3.5 & 87.3 & 14.3 & 52.8 & 5.5 & 8.6 & 1.3 \\
\hline & Standard deviation & 0.3 & 581 & 2.7 & 166.0 & 12.6 & 65.0 & 1.0 & 15.3 & 1.9 \\
\hline & Minimum & 6.2 & 137 & 0.1 & 13.0 & 3.9 & 23.4 & 3.4 & 3.1 & 0.3 \\
\hline & Maximum & 7.2 & 2340 & 9.3 & 516.2 & 43.2 & 246.4 & 6.5 & 48.0 & 5.4 \\
\hline
\end{tabular}

of conductivity and content of individual ions indicates that the properties of water of the studied wetlands are predominantly shaped by precipitation. This may result from the structure of vegetation, which is characterized by a relatively loose tree stand.

If compared to the presented properties of the water of peat bog habitats, water in the basins affected by runoff from the ring road showed very high values of electrical conductivity and a much higher, close to neutral reaction (Fig. 3). This indicates a much greater mineralisation and alkalisation of these waters.

Mean and median conductivity of water in this group are more than 10-fold higher than those observed in the natural wetland areas. The observed maximum values for electrical conductivity exceeded significantly $1000 \mu \mathrm{S} \mathrm{cm}^{-1}$. Moreover, in this group there is very high variability of the analysed properties (Table 3 ).

The ionic composition indicated the dominance of chloride and sodium ions. Their concentration was more than 10-fold higher than that found in the waters of the reservoirs not affected by the runoff. This corresponds to the very high concentration of these ions in the snowmelt runoff, caused by water penetration into road salt used during winter.

Besides high concentrations of chloride and sodium there is also a significantly higher content of other ions, such as calcium and magnesium as well as nitrates and sulphates, than in the naturally-charged reservoirs. From amongst the analysed ions, only the concentration of potassium showed no significant differences between the study areas of wetlands (Fig. 4).

\section{Discussion}

In the selected outflowless catchments of natural character of water supply (Z3, Z4, Z5), ombrogenic oligo- or mesotrophic acidic water wetlands were found, typical of the Plateau of Gdansk, while the water chemistry of the wetlands contaminated by the road runoff (Z1 and Z2) is clearly different.
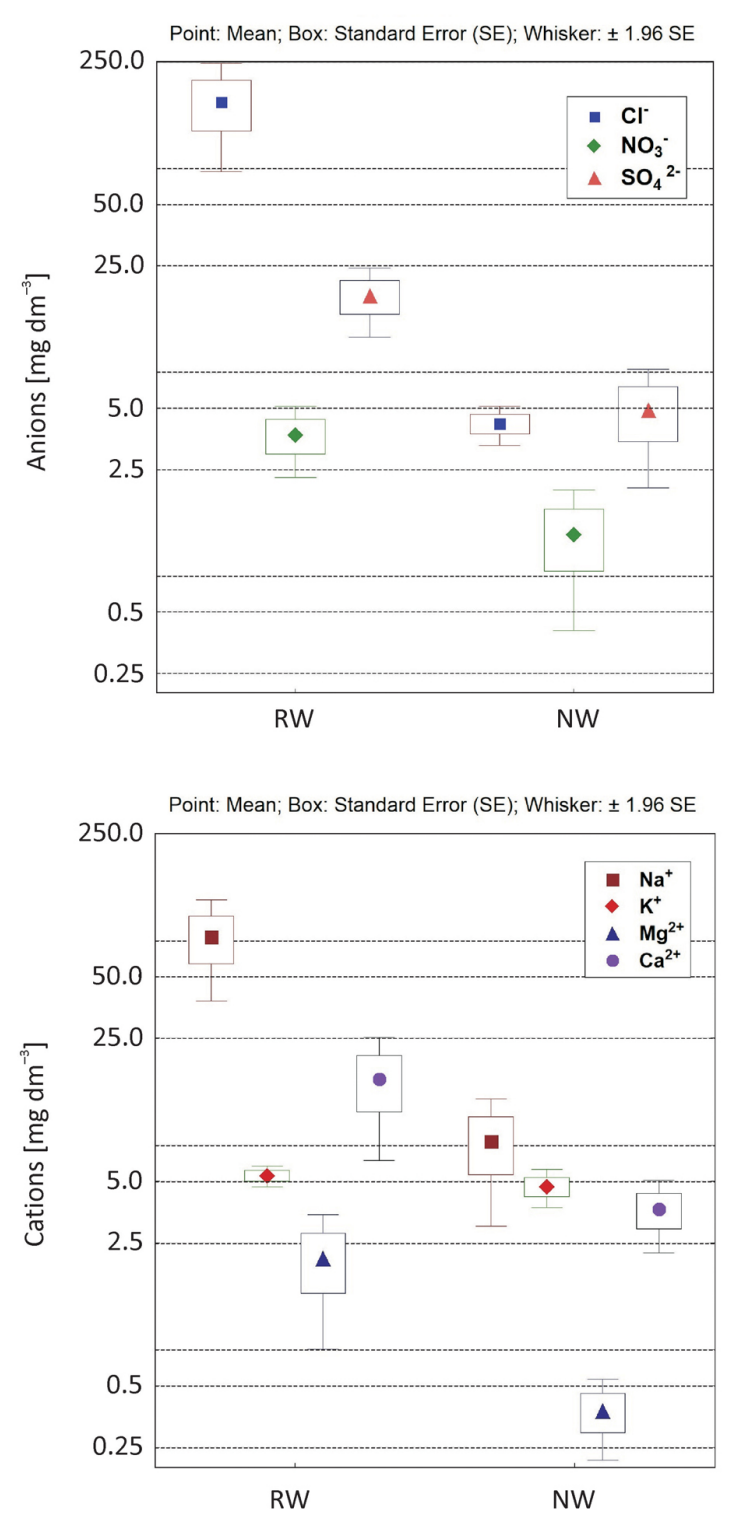

Fig. 4. Concentration of major ions in surface waters Explanation: RW - wetlands under the influence of runoff from the Ring Road, NW - natural wetlands 

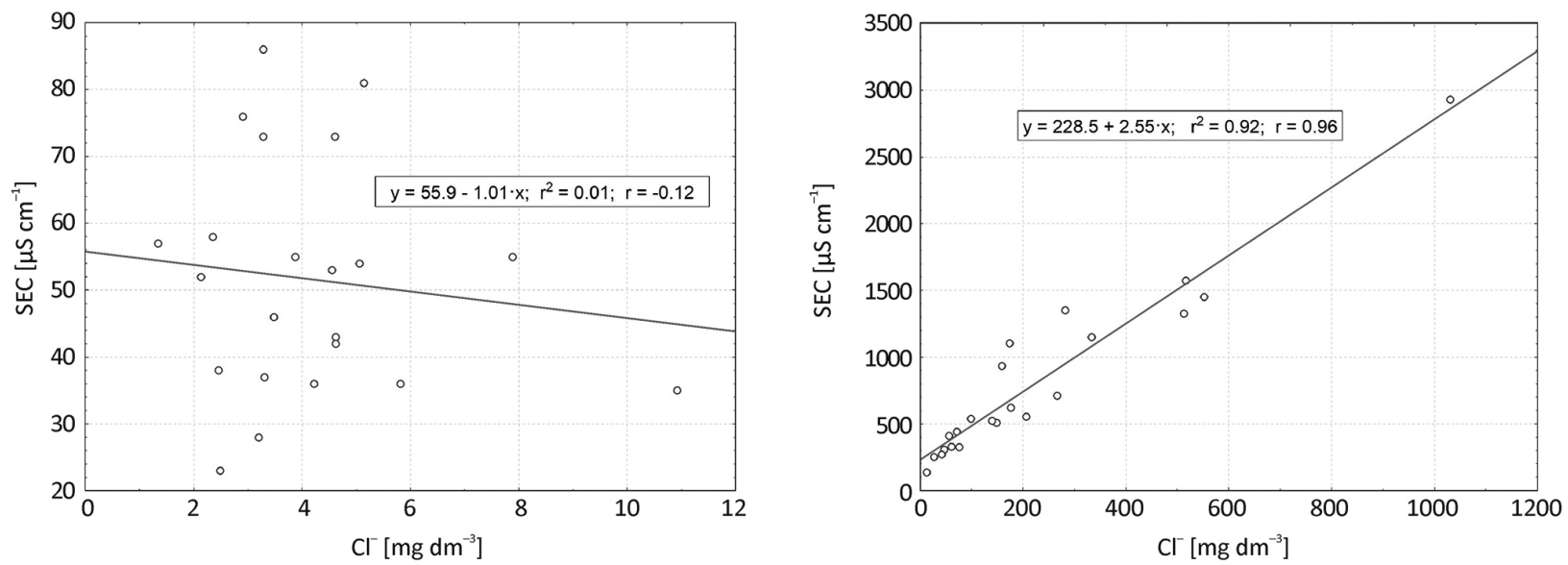

Fig. 5. Dependency between the concentration of chlorides and specific conductivity of surface water from the natural reservoirs (left) and those supplied by the runoff from the Ring Road (right)

Temporal variations in conductivity as a derivative of the concentration of dissolved ions, clearly refers to the changes in this parameter in the runoff from the road surface which charges the studied wetlands (see Fig. 2). High values of $500-1000 \mu \mathrm{S} \mathrm{cm}^{-1}$ and over were recorded in the observed points mostly between February and May, at the times corresponding to the period of highest concentration in the runoff (see Fig. 2 and Table 2). The long-term persistence of such a level was primarily related to a significant amount of sodium chloride accumulated on the road surface and its sides during long and cold winter periods. However, much lower conductivity in the summer and autumn refers to the reduced value of this ratio during periods of relatively clean rainwater runoff, especially after heavy rainfall.

The results of the analyses confirmed the crucial role of the supply of dissolved mineral salts, mainly sodium chloride, on the overall mineralization of wetlands supplied by water runoff from the ring road. A strong and statistically significant linear relationship between the concentration of chlorides and the conductivity of the wetland water was identified. This dependency is described by a high value of the Pearson's correlation coefficient $\mathrm{R}=0.96$, compared to irrelevant or low coefficients of the similar relation for the waters of natural wetlands: $\mathrm{R}=-0.12$ (Fig. 5). These results indicate that the general physical and chemical properties of the water of endorheic basins is affected by saline runoff from the ring road.

The important role of sodium chloride, used for controlling snow cover on roads, for water chemistry is indicated by, among others (Marsalek 2003; Thunqvist 2003), as well as (Sriyaraj and Shutes 2001). Salinity and a significantly higher concentration of ions, including sulphate and nitrate contents, in road runoff are common on urban roads with high traffic density (Polkowska et al. 2001).
The water from roads often adds to the accumulation of mineral and organic material. This leads to the creation of silt-covered ground, especially in the marginal parts of the examined habitats. Their development completely transforms the habitat conditions and leads to the disappearance of peat-forming processes. At the same time, besides hydrochemical factors, the increased amplitude and frequency of water level fluctuations caused by runoff from the road surface seems to be also very important for changes in wetland ecosystems. This is closely related to the transformation resulting from the development of the road system in the catchment area and changes in the nature of the substrate. The analysis of the current and historical digitalised cartographic data, based on MapInfo GIS software, revealed that some catchment areas increased by up to $0.02 \mathrm{~km}^{2}$ of paved road surface, which has a very high runoff coefficient $\mathrm{C}=0.90$. This means that for typical rainfall of $\mathrm{q}=1500 \mathrm{dm}^{3} \mathrm{~s}^{-1} \mathrm{~km}^{-2}$ the runoff is increased by about 10 to $13 \mathrm{dm}^{3} \mathrm{~s}^{-1}$ and of course much more during heavy rainfalls. In the case of the small elementary catchments which were analysed (area mostly about $0.05-0.2 \mathrm{~km}^{2}$ ) these values should be considered as significant.

\section{Conclusions}

The results of this study indicate that the physicochemical properties of water of natural small endorheic basins within the Plateau of Gdansk are primarily under the influence of precipitation. Hydrochemical characteristics, such as low conductivity (mineralisation) and $\mathrm{pH}$ at a range from 5.2 to 5.4, refer explicitly to the property of rainfall. It was found that the hydrochemical regime of the small endorheic wetlands was transformed by runoff from the highway. Their properties are significantly different from the natural waters of such objects in the investigated area. 
These differences are very clearly manifested by the total mineralisation of water, its alkalinisation and significantly higher concentration of most major ions, such as $\mathrm{Na}^{+}, \mathrm{Ca}^{2+}, \mathrm{Mg}^{2+}, \mathrm{Cl}^{-}, \mathrm{SO}_{4}^{2-}, \mathrm{NO}_{3}^{-}$. Particularly high levels of chloride and sodium in the waters of these wetlands confirm the dominant role of these ions in shaping the chemical composition of the waters of the tested objects. The results indicate that the influence on the formation of general physical and chemical properties of the runoff from roads and, consequently, on the water from the endorheic wetlands, is exerted by substances such as $\mathrm{NaCl}, \mathrm{CaCl}_{2}$ and $\mathrm{MgCl}_{2}$, which are widely used as a means of winter road maintenance.

A strong and statistically significant linear relationship between the concentration of chloride and electrolytic conductivity of the water of these wetlands was recorded. These interdependencies are described by the high value of Pearson's correlation coefficient $\mathrm{R}=0.96$, especially if compared to irrelevant or low coefficients of the analogous interdependencies for the natural wetlands waters, i.e. $\mathrm{R}=-0.12$.

The endorheic wetland areas affected by the runoff water from the test ring road shows very large fluctuations in the values of the studied parameters and their clear seasonality. The highest content of dissolved ions as well as conductivity and $\mathrm{pH}$ occurred during early spring (February-May), while in summer and autumn they were significantly lower. A strongly marked seasonality of chemical composition of these waters is another feature which differs them from the natural water of the wetland habitats of the Plateau of Gdansk. The results of the studies showed that the properties of water are significantly different throughout the entire year, indicating a strong and lasting transformation of their hydrochemical regime.

Fluctuations in the water observed in aquatic and wetland ecosystems charged by the runoff from roads are sometimes very violent. In the case of endorheic basins they are characterized by high amplitudes of water levels. In some cases they substantially exceed the variability of water levels recorded in natural water reservoirs and wetlands found in the area of research.

Therefore, the design work associated with the operation of drainage from the planned road investments should be preceded by an inventory of the adjacent natural areas, with a particular emphasis on aquatic and ombrogenic wetland ecosystems as particularly sensitive to changes in the hydrochemical regime. It should also be noted that the current practice in road planning by the General Directorate for National Roads and Motorways, which shows a preference for the construction of artificial reservoirs of road runoff in the immediate vicinity of the roads, seems to be right and may be effective in protecting sensitive wetland ecosystems.

\section{References}

Dubiella-Jackowska A., Astel A., Polkowska Ż., Staszek W., Kudłak B., Namieśnik J., 2010, Atmospheric and surface water pollution interpretation in the Gdansk Beltway impact range by the use of multivariate analysis, CLEAN Soil, Air, Water 38(9): 865-876.

Kostrzewski A., Kruszyk R., 2010, Opracowanie sprawozdania pt. „Raport o stanie geoekosystemów Polski w roku 2009 (Elaboration of the report entitled "Report on the state of geoecosystems in Poland in 2009") [Online], GIOŚ, Warszawa, $98 \mathrm{pp}$ [in Polish]. Retrieved from http://www.gios. gov.pl/zmsp/stan2009/stan2009.html [accessed 16 May 2017].

Marsalek J., 2003, Road salts in urban stormwater: an emerging issue in stormwater management in cold climates, Water Sci. Technol. 48(9): 61-70.

Marsalek J., Oberts G., Exall K., Viklander M., 2003, Review of operation of urban drainage systems in cold weather: water quality considerations, Water Sci. Technol. 48(9): 11-20.

Mazurek M., Zwoliński Zb., 2001, Stan geoekosystemów Polski w roku 2000 (The state of geoecosystems in Poland in 2000) [Online], Instytut Badań Czwartorzędu i Geoekologii UAM, Poznań, 52 pp [in Polish]. Retrieved from http://main.amu.edu.pl/ zmsp/stan99/stan99.html [accessed 8 May 2017].

Osmulska-Mróz B., Sadkowski K., 1991, Zanieczyszczenie spływów opadowych $\mathrm{z}$ dróg szybkiego ruchu $\mathrm{w}$ Polsce (Stromwater runoff pollution from highways in Poland), Ochr. Środ. Zasob. Natur. 2: 73-84 [in Polish].

Osmulska-Mróz B., 1997, Problemy ochrony środowiska wodnego w rejonie dróg (Problems of water protection in surroundings of highways), Ochr. Środ. Zasob. Natur. 11: 65-83 [in Polish].

Polkowska Ż., Grynkiewicz M., Zabiegała B., Namieśnik J., 2001, Levels of pollutants in runoff water from Road with high traffic intesivity in the city of Gdańsk, Poland, Pol. J. Environ. Stud. 10(5): 351-363.

Sriyaraj K., Shutes R.B.E, 2001, An assessment of the impact of motorway runoff on a pond, wetland and stream, Environ. Int. 26(5-6): 433-439.

Thunqvist EL., 2003, Increased chloride concentration in a lake due to deicing salt application, Water Sci. Technol. 48(9): 51-59.

Tylkowski J., 2013, Stan geoekosystemów Polski w roku 2012 na podstawie badań Zintegrowanego Monitoringu Środowiska Przyrodniczego (The state of geoecosystems in Poland in 2012 on the basis of the Integrated Monitoring of the Environment) [online], Stacja Monitoringu Środowiska Przyrodniczego UAM w Białej Górze, Biała Góra, 62 pp [in Polish]. Retrieved from http://www.staff. amu.edu.pl/ $\sim$ Zmsp/stan2012/ZMSP2012.pdf [accessed 26 May 2017].

Westerlund C., Viklander M., Backstrom M., 2003, Seasonal variations in road runoff quality in Lulea, Sweden, Water Sci. Technol. 48(9): 93-101. 